\title{
LIVER FUNCTION TESTS IN RHEUMATOID ARTHRITIS
}

\author{
BY \\ P. W. DARBY \\ From the Department of Chemical Pathology, Westminster Hospital Medical School, London
}

(RECEIVED FOR PUBLICATION JUNE 23, 1955)

Interest in liver function in rheumatoid arthritis has arisen from investigations into the aetiology of the disease and from the observation that an attack of jaundice may induce a remission (Hench, 1940). Laboratory studies have, however, given conflicting results. Impaired glucose tolerance was found by Pemberton and Foster (1920) and by Andrews and Muether (1941) and Flynn and Irish (1946). Rawls, Weiss, and Collins (1937, 1939) in a detailed study of 100 cases came to the conclusion that liver function was definitely impaired. Using the dye azorubin $\mathbf{S}$ they found that $55 \%$ of the cases gave abnormal results. In many of these, however, the dye appeared in the bile much more rapidly than normal, a phenomenon which the authors ascribed to liver irritability. This interpretation has been criticized by Lyon and Wirts (1937), and exclusion of these cases reduces the abnormal results to $19 \%$. This test has never become widely used, because it requires duodenal intubation, though Rosenberg and Soskin (1940) found it at least as sensitive as the more familiar bromsulphalein test. Bromsulphalein (B.S.P.) was used by Robinson (1943) with negative results ; he had, however, considerably modified the test as commonly used, and his B.S.P. "index" was based on blood levels found during 7.25 minutes following injection of $3.5 \mathrm{mg}$. per $\mathrm{kg}$. Recent work on the fate of injected B.S.P. has shown that this time is too short for the demonstration of all but severe liver damage ; the percentage disappearance rate from plasma does not fall off unless a larger dose of B.S.P. is used and time is allowed for the liver to become "saturated" with the dye (Ingelfinger, Bradley, Mendeloff, and Kramer, 1948 ; Mendeloff, Kramer, Ingelfinger, and Bradley, 1949). Movitt and Davis (1953) have also used B.S.P. in rheumatoid arthritis, and found a small degree of dye retention (up to $3 \%$ ) in seven out of 15 cases.

Abnormal results have been obtained with the hippuric acid test by several workers (Rawls, Weiss, and Collins, 1939 ; Lövgren, 1953 ; Kersley, Mandel, and Jeffrey, 1953) ; this test is, however, open to the objection that impairment of renal function may also give low values. The occurrence of serum protein changes in rheumatoid arthritis is now well established, and they account for the positive flocculation tests which are found in a proportion of cases (Carter and Maclagan, 1946 ; Kersley et al., 1953 ; Poulsen, 1949), but they are not necessarily indicative of impairment of liver function.

\section{The Present Investigation}

Impaired hepatic function has been reported in shock (Zamcheck, Chalmers, White, and Davidson, 1950), in fever (Hicks, Holt, Guerrant, and Leavell, 1948), and following spinal cord injury (Cooper, Rynearson, and MacCarty, 1951). It is likely that the poor performance of liver function tests in these patients was due to hepatic circulatory change rather than true parenchymal damage. Similarly in rheumatoid arthritis the presence of such factors as reduced physical activity, occasional pyrexia, the degree of appetite, and so on, might influence the performance of the liver when subjected to certain tests. Accordingly a control series of hospital patients was studied in parallel with the rheumatoid series so that these non-specific factors could be taken into account in evaluating the results.

Clinical Material.- Tests were carried out on 50 cases of rheumatoid arthritis, of which 41 were attending the rheumatism clinic at Westminster Hospital and nine were in-patients at the hospital. The control series of 45 patients consisted of 15 cases of hypertension, seven of chronic bronchitis, five of osteoarthritis, four of fibrositis, three of obesity and psychoneurosis, three of anxiety neurosis, two of menopausal symptoms, and one case each of mitral stenosis with anxiety neurosis, sciatica, convalescent pneumonia, osteoporosis, erythema nodosum with anaemia, and anaemia due to menorrhagia. The rheumatoid and control groups were similar in age and sex distribution and contained the same proportion of ambulant cases.

Methods.-The following tests were carried out : Serum bilirubin (Malloy and Evelyn, 1937), urine 
urobilinogen (Schwartz, Sborov, and Watson, 1944), bromsulphalein retention (Mateer, Baltz, Marion, and MacMillan, 1943), total urine coproporphyrin (Schwartz, Hawkinson, Cohen, and Watson, 1947 ; Schwartz, Zieve, and Watson, 1951, modified), thymol turbidity (Maclagan, 1944a) and flocculation (Maclagan, 1947), serum colloidal gold (Maclagan, 1944b), zinc sulphate turbidity (Kunkel, 1947), and ammonium sulphate turbidity (de la Huerga and Popper, 1950).

\section{Results}

Serum Bilirubin and Urine Urobilinogen.-Results of these estimations were within the normal range in both rheumatoid and control groups.

Bromsulphalein Retention.-The distribution of results with this test is shown in Fig. 1. Mateer et al. (1943) and Lippincott, Hesselbrock, Ellerbrook, Gordon, and Rhees (1946) have shown that in normal subjects less than $10 \%$ of injected B.S.P. remains in the circulation 30 minutes after an intravenous dose of $5 \mathrm{mg}$. per $\mathrm{kg}$. In the present rheumatoid arthritis series, 11 out of 47 cases in which
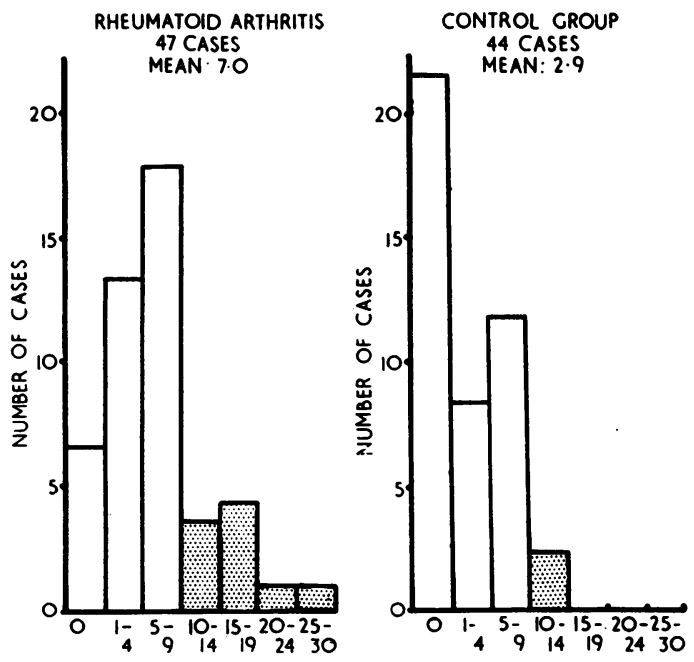

FIG. 1.-Histogram showing the distribution of bromsulphalein retention values in the two groups. Abnormal values are shown shaded. The proportions of cases showing retention were in the rheumatoid group 0.87 and in the control group 0.5 . $\frac{\text { Difference between proportions }}{\text { Standard error of difference }}=3.1$

the test was carried out $(23 \%)$ showed dye retention of $10 \%$ or more compared with two out of 44 cases $(4.5 \%)$ in the control group. These abnormal results are shown shaded in Fig. 1. The proportion of cases showing some degree of B.S.P. retention were in the rheumatoid group $0.87(87 \%)$ and in the control group $0.5(50 \%)$. The difference is statistically significant (difference between proportions/standard error of the difference $=3.1$ ).

Urine Coproporphyrin Excretion.-This estimation was chosen because of its sensitivity as an index of liver function. Watson, Hawkinson, Capps, and Rappaport (1949) have reported that it is frequently $\overparen{\curvearrowright}$ the last test to become negative following an attack of infective hepatitis. Normally about four-fifths of the total coproporphyrin eliminated is excreted into the bile and appears in the faeces, the remaining one-fifth being excreted by the kidneys. In liver damage or biliary obstruction an increased amount $\frac{8}{8}$ appears in the urine because of impaired excretion 6 into the bile or biliary stasis. The test is a valid one $\mathrm{r}$ for liver function provided other causes of enhanced $\vec{G}$ values are excluded, e.g., lead poisoning, poisoning by other chemicals, and pernicious and aplastic anaemias (Watson and Larson, 1947).

Schwartz et al. (1951) quote $160 \mu \mathrm{g}$. as the normal $\underbrace{2}$ 24-hour output of urine coproporphyrin. Raine (1952) recommends a shorter collection time owing $\mathcal{E}$ to difficulty in preserving 24 -hour collections without

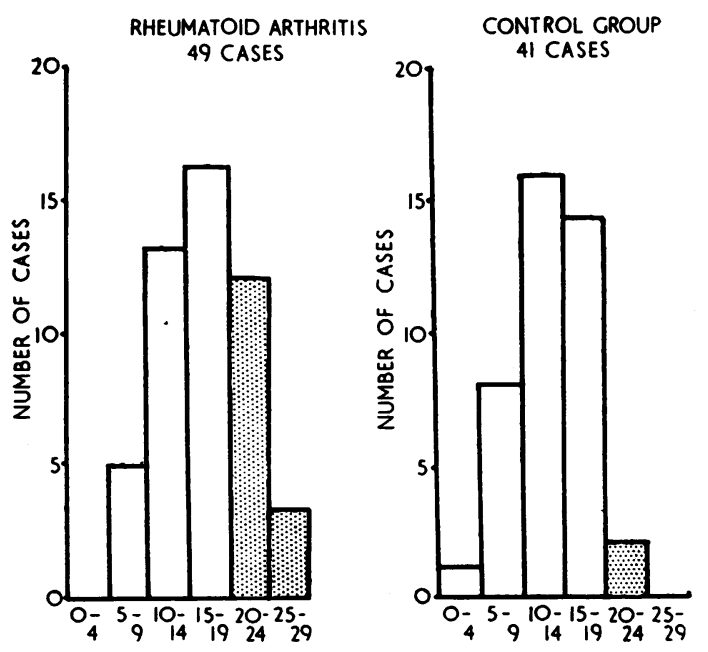

FIG. 2.-Histogram showing the distribution of corproporphyrin $\mathrm{N}$ output values in the two groups. Abnormal results are shown $\omega$ shaded. Mean value in the rheumatoid group $=16.9 \mu \mathrm{g}$.; S.D. $\sigma$ 5.8. Control group : $\operatorname{mean}=13.1 \mu \mathrm{g}$. ; S.D. 4.6. Difference between means $=3.8 ; t=3.8 ; P=$ less than 0.001

loss of porphyrin, and quotes an estimated daily $\stackrel{\mathscr{\complement}}{+}$ output of $200 \mu \mathrm{g}$. (Raine, 1950). In the present $\frac{T}{T}$ study afternoon collections of two hours were made.

The urine after acidification was extracted with $\stackrel{\square}{\stackrel{D}{\circ}}$ three portions of ether ; non-fluorescent precursors $\stackrel{\mathbb{Q}}{\varrho}$ were oxidized with iodine and the porphyrin extracted with hydrochloric acid. After purification 
the porphyrin was estimated by comparison with a standard prepared from pure coproporphyrin in the Hilger fluorimeter. Duplicate analyses and recovery experiments were satisfactory. Normal values for this technique were established by estimations carried out on 26 healthy subjects, and values of up to $20 \mu \mathrm{g}$. in two hours were found (mean 11.6, S.D. 4.1). The results obtained in the rheumatoid and control groups are shown in Fig. 2. In the rheumatoid group 15 out of 49 cases (31\%) showed a urine excretion greater than $20 \mu \mathrm{g}$. coproporphyrin in two hours. In the control group only two out of 41 cases $(5 \%)$ showed enhanced values. These abnormal results are shown shaded in Fig. 2. The mean values were in the rheumatoid group $16.9 \mu$ g. (S.D. 5.8) ; in the control group $13.1 \mu \mathrm{g}$. (S.D. 4.6). The difference between the mean values is highly significant (difference between means= $3.8 ; \mathrm{t}=3.8 ; \mathrm{P}=$ less than 0.001 ).

Flocculation Tests.-The numbers of positive tests in the two groups are set out in Table I. The

TABLF. I ABNORMAL RESULTS WITH THE FLOCCULATION

\begin{tabular}{|c|c|c|c|c|c|c|}
\hline \multicolumn{3}{|c|}{ Test } & \multicolumn{2}{|c|}{$\begin{array}{c}\text { Rheumatoid } \\
\text { Arthritis } \\
\text { (48 Cases) }\end{array}$} & \multicolumn{2}{|c|}{$\begin{array}{c}\text { Control } \\
\text { Group } \\
\text { (42 Cases) }\end{array}$} \\
\hline $\begin{array}{l}\text { Thymol turbidity (no } \\
\text { Thymol turbidity (no } \\
\text { Thymol flocculation } \\
\text { Serum colloidal gold } \\
\text { Zinc sulphate } \\
\text { Ammonium sulphate }\end{array}$ & $\begin{array}{l}10-2 \text { un } \\
10-4 \text { un } \\
\ldots \\
\ldots \\
\cdots \\
\cdots\end{array}$ & $\begin{array}{l}\text { s) } \\
\text { s) } \\
\cdots \\
\cdots \\
\cdots \\
\cdots\end{array}$ & $\begin{array}{r}26 \\
9 \\
13 \\
19 \\
26 \\
21\end{array}$ & $\begin{array}{l}(54 \%) \\
(19 \%) \\
(27 \%) \\
(40 \%) \\
(54 \%) \\
(44 \%)\end{array}$ & $\begin{array}{r}10 \\
0 \\
1 \\
2 \\
14 \\
2\end{array}$ & $\begin{array}{l}(24 \%) \\
(2 \%) \\
(5 \%) \\
(33 \%) \\
(5 \%)\end{array}$ \\
\hline Total (one or more te & ositive) & . & 35 & $(73 \%)$ & 17 & $(40 \%)$ \\
\hline
\end{tabular}

high proportion of positive results in the control group is noteworthy and clearly indicates the nonspecific nature of these tests.

\section{Discussion}

The most important results obtained are those with the B.S.P. and coproporphyrin tests. A significant number of abnormal results have been obtained with the B.S.P. test, the highest value recorded being $25 \%$ retention. There has in the past been some controversy regarding the mode of excretion of B.S.P. The rapid initial fall of blood levels following injection has been considered to be due to absorption by reticulo-endothelial cells, and this view received some support from the work of Klein and Levinson (1933), who produced increased B.S.P. retention in dogs by splenectomy and by india ink blockade. However, Mendeloff et al. (1949) have pointed out that the effect of splenectomy can be explained by a reduction in blood flow or by a nonspecific effect of a surgical operation which may impair removal of B.S.P. for two weeks. India ink may well have a direct toxic effect on the liver, and the swollen ink-laden phagocytes may prevent adequate exposure of the polygonal cells to blood. Krebs and Brauer (1949) have prepared autoradiographs of liver sections following injection of radioactive B.S.P. in rats and have shown that uptake of B.S.P. does not involve Kupffer cells but proceeds directly from plasma into the polygonal cells. Bromsulphalein is now widely accepted as a simple, reliable, and sensitive index of liver function, and is of particular value in non-icteric cases.

The highest value obtained for urine coproporphyrin in the rheumatoid series was $29.5 \mu \mathrm{g}$. in two hours. Compared with the two- or three-fold increase obtained in the infective hepatitis cases reported by Watson et al. (1949) this represents a relatively mild degree of liver damage as judged by this test. In biliary obstruction a five-fold increase is possible, and greatly enhanced values may be found in errors of porphyrin metabolism.

Results with all the tests which gave positive results are compared in Table II. The degree of correlation between the various tests was not statist-

TABI.E II

COMPARISON OF TESTS

\begin{tabular}{ll|c|c}
\hline \multirow{2}{*}{ Test } & \multicolumn{3}{|c}{ Abnormal Results } \\
\cline { 2 - 4 } & & Rheumatoid Arthritis & Control Group \\
\hline Bromsulphalein & $\cdots$ & $11(23 \%)$ & 2 \\
Coproporphyrin & $\cdots$ & $15(31 \%)$ & $2 \%)$ \\
Flocculation tests & $\cdots$ & $35(73 \%)$ & $17(40 \%)$ \\
\hline
\end{tabular}

ically significant except within the group of flocculation tests. No relationship could be established between the presence of liver damage and the severity or duration of the rheumatoid condition, and there was no difference between the proportions of positive results in treated and untreated patients. The results of Rawls et al. $(1937,1939)$ are, however, confirmed, in that a proportion of cases of rheumatoid arthritis-between one-quarter and one-third of the present series-do show evidence of impaired liver function. A small number of weakly positive tests was found in the control series, but it is clear from the statistical analysis that there exists in rheumatoid arthritis a degree of hepatic damage which is not found in other kinds of chronic illhealth.

\section{Summary}

Liver function tests have been carried out in 50 cases of rheumatoid arthritis and in a control series of 45 patients with chronic ill-health. 
All cases showed normal serum bilirubin and urine urobilinogen levels.

Abnormal bromsulphalein retention was found in $23 \%$ and elevated urine coproporphyrin output in $31 \%$ of the rheumatoid cases.

The significance of these findings has been discussed.

I wish to thank Dr. F. Dudley Hart for access to his cases, and Professor N. F. Maclagan for valuable advice and criticism.

\section{REFERENCES}

Andrews, K. R., and Meuther, R. O. (1941). J. Lab. clin. Med., 26, 675.

Carter, A. B., and Maclagan, N. F. (1946). Brit. med. J., 2, 80.

Cooper, I. S., Rynearson, E. H., and MacCarty, C. S. (1951). J. Lab. clin. Med., 38, 689.

de la Huerga. J and Popper, H. (1950). Ibid., 35, 459.

Flynn, J. E., and Irish, O. J. (1946). Science, 104, 344

Hench, P.S. (1940). Med. Clin. N. Amer., 24, 1209.

Hicks, M. H., Holt, H. P., Guerrant, J. L., and Leavell, B. S. (1948). J. clin. Invest., 27, 580 .

Ingelfinger, F. J., Bradley, S. E., Mendeloff, A. I., and Kramer, P. (1948). Gastroenterology, 11, 646.

Kersley, G. D., Mandel, L., and Jeffrey, M. R. (1953). Ann. rheum. Dis., 12, 29.
Klein, R. I., and Levinson, S. A. (1933). Proc. Soc. exp. Biol. (N.Y.), 31, 179.

Krebs, J., and Brauer, R. W. (1949). Fed. Proc., 8, 310.

Kunkel, H. G. (1947). Proc. Soc. exp. Biol., N.Y., 66, 217.

Lippincott, S. W., Hesselbrock, W. B., Ellerbrook, L. D., Gordon, H. H. and Rhees, M. C. (1946). Amer. J. clin. Path., 16, 188.

Lövgren, O. (1953). Ann. Med. intern. Fenn., 42, 42

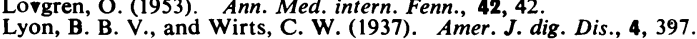

Malloy, H. T., and Evelyn, K. A. (1937). J. biol. Chem., 119, 481.

Maclagan, N. F. (1944a). Brit. J. exp. Path., 25, 234. (1944b). Ibid., 25, 15

(1947). Brit. med. J., 2, 197

Mateer, J. G., Baltz, J. I, Marion, D. F., and MacMillan, J. M (1943). J. Amer. med. Ass., 121, 723.

Mendeloff, A. I., Kramer, P., Ingelfinger, F. J., and Bradley, S. E. (1949). Gastroenterology, 13, 222.

Movitt, E. R., and Davis, A. E. (1953). Amer. J. med. Sci., 226, 516.

Pemberton, R., and Foster, G. L. (1920). Arch. intern. Med., 25, 243.

Poulse 1, E. (1949). Acta med. scand., Suppl. 234, 268.

Raine, D. N. (1950). Biochem. J., 47, xiv.

(1952). Personal communication.

Rawls, W. B., Weiss, S., and Collins, V. L. (1937). Ann. intern. Med., 10, 1021 .

Robinson, (1939). Ibid., 12, 1455

Resenter, Ann. rheum. Dis., 3, 207.

H., and Soskin, S. (1940). Ann. intern. Med., 13, 1644.

Schwartz, S. Hawkinson, V., Cohen, S, and Watson, C, J. (1947). J. biol. Chem., 168, 133.

-Sborov, V., and Watson, C. J. (1944). Amer. J. clin. Path., 14, 598.

Zieve, L., and Watson, C. J. (1951). J. Lab. clin. Med., 37, 843.

Watson, C. J., and Larson, E. A. (1947). Physiol. Rev., 27, 478.

Hawkinson, V., Capps, R. B., and Rappaport, E. M. (1949). J. clin. Invest. 28,621 .

Zamcheck, N., Chalmers, T. C., White, F. W., and Davidson, C. S. (1950). Gastroenterology, 14, 343. 